\title{
Incidence and virulence characteristics of Aeromonas spp. in fish
}

\author{
Ashraf M. Abd-El-Malek
}

Department of Food Hygiene (Meat Hygiene), Faculty of Veterinary Medicine, Assiut University, 71515 Assiut, Egypt.

Corresponding author: Ashraf M. Abd-El-Malek, e-mail: ashraf7702001@yahoo.com

Received: 20-09-2016, Accepted: 14-12-2016, Published online: 12-01-2017

doi: 10.14202/vetworld.2017.34-37 How to cite this article: Abd-El-Malek AM (2017) Incidence and virulence characteristics of Aeromonas spp. in fish, Veterinary World, 10(1): 34-37.

\begin{abstract}
Aim: This study was conducted to evaluate the presence of Aeromonas spp. in raw and ready-to-eat (RTE) fish commonly consumed in Assiut city, Egypt, and to determine virulence factors due to they play a key role in their pathogenicity.

Materials and Methods: A total of 125 samples of raw and RTE fish samples were taken from different fish markets and fish restaurants in Assiut Governorate and screened for the presence of Aeromonas spp. by enrichment on tryptic soy broth then incubated at $30^{\circ} \mathrm{C}$ for $24 \mathrm{~h}$. Plating unto the sterile Petri dishes containing Aeromonas agar base to which Aeromonas selective supplement was added. The plates were incubated at $37^{\circ} \mathrm{C}$ for $24 \mathrm{~h}$. Presumptive Aeromonas colonies were biochemically confirmed and analyzed for pathogenicity by hemolysin production, protease, and lipase detection.

Results: The results indicated that raw fish were contaminated with Aeromonas spp. (40\% in wild and $36 \%$ in cultured Nile tilapia). Regarding RTE, Aeromonas spp. could be isolated with the percentage of $16 \%, 28 \%$ and $20 \%$ in fried Bolti, grilled Bolti and fried Bayad, respectively. Out of 35 isolates obtained, 22 were categorized as Aeromonas hydrophila, 12 were classified as Aeromonas sobria and Aeromonas caviae were found in only one isolate. The virulence factors of Aeromonas spp. were detected and the results showed that all isolates produced of hemolysin $(91.4 \%)$, protease $(77.1 \%)$, and lipase enzyme (17.1\%).
\end{abstract}

Conclusion: This study indicates that the presence of $A$. hydrophila with virulence potential in fresh and RTE fish may be a major threat to public health.

Keywords: Aeromonas hydrophila, fish, hemolysin, lipase, protease enzyme, public health.

\section{Introduction}

The most popular and commonly consumed freshwater fish species in Egypt are Nile tilapia (Bolti) and Bayad (Bagrus bayad). Grilled fish is food for common consumption in different parts of the world as well as in Egypt. Furthermore, frying of fish is practiced in some parts of the world.

Aeromonas is an emerging pathogen and is recognized to cause a variety of diseases in humans. This pathogen is associated with food poisoning and some human diseases as gastroenteritis and extraintestinal symptoms such as soft-tissue, muscle infections, septicemia, and skin diseases in humans [1].

Of the Aeromonas spp., Aeromonas hydrophila, Aeromonas Sobria, and Aeromonas caviae have been incriminated as the main causes of Aeromonas associated human diseases [2].

It has been established that hemolysin is a virulence factor contributing to the pathogenesis of A. hydrophila infection. Furthermore, fish plays an important role in the transmission of Aeromonas spp. to humans [3].

Copyright: Ashraf M. Abd-El-Malek. Open Access. This article is distributed under the terms of the Creative Commons Attribution 4.0 International License (http://creativecommons.org/licenses/ by/4.0/), which permits unrestricted use, distribution, and reproduction in any medium, provided you give appropriate credit to the original author(s) and the source, provide a link to the Creative Commons license, and indicate if changes were made. The Creative Commons Public Domain Dedication waiver (http:// creativecommons.org/publicdomain/zero/1.0/) applies to the data made available in this article, unless otherwise stated.
There is scarce of the published information and limited studies about the prevalence of Aeromonas spp. especially $A$. hydrophila and their virulence in raw and ready-to-eat (RTE) fish in Assiut city, Egypt.

Keeping in view the importance of these pathogens, therefore, the aim of this study was conducted to isolate and identify of Aeromonas spp. from raw fish and RTE fish samples in Assiut city, Egypt. In addition to determine the most virulence factors (such as hemolysin, protease and lipase) which play a key role in their pathogenicity.

\section{Materials and Methods}

\section{Ethical approval}

Not required for this study.

\section{Sampling and isolation of Aeromonas spp.}

Raw fish samples consisted of wild Nile tilapia and cultured Nile tilapia (25 of each) which was randomly collected under aseptic conditions from different fish markets at Assiut city. Raw fish samples were stored in icebox with an appropriate quantity of crushed iced for transportation to the laboratory within $1 \mathrm{~h}$. Regarding RTE fish samples included grilled Bolti and fried Bolti as well as fried Bayad samples (25 of each) which were collected as sold to the consumers in sterile plastic bags from different fish restaurants in Assiut city. All samples were labeled and transferred directly within $1 \mathrm{~h}$ to the laboratory, where immediately examined. Preparation of samples performed as recommended by Sanaa [4]. Isolation 
was done by enrichment on tryptic soy broth (Biolife, $\mathrm{CP} 4712$ ) then incubated at $30^{\circ} \mathrm{C}$ for $24 \mathrm{~h}$. Plating unto the sterile Petri dishes containing Aeromonas agar base (Biolife, CN0801) to which Aeromonas selective supplement (Ampicillin) was added. The plates were incubated at $37^{\circ} \mathrm{C}$ for $24 \mathrm{~h}$ [5]. Presumptive Aeromonas colonies were biochemically confirmed according to Table-1 [6].

Detection of some virulence factors of A. hydrophila [7] Hemolysin production

A. hydrophila tested for hemolysin production on blood base agar (Britania, Argentina) supplemented with $5 \%$ sheep blood. A loopful of an overnight growth from nutrient agar was cultured on blood agar by streaking method, incubated at $37^{\circ} \mathrm{C}$ for $24 \mathrm{~h}$.

\section{Production of protease}

Protease was determined on $2 \%$ agar-agar (Qualikems, India) containing 10\% (w/v) skimmed milk.

\section{Lipase detection}

Lipase detection was performed on olive oil with phenol red agar. The serial diluted bacterial samples were plated on phenol red agar and incubated at $37^{\circ} \mathrm{C}$ overnight. The phenol red agar plates were prepared by incorporating phenol red $(0.01 \% \mathrm{w} / \mathrm{v})$, olive oil $(0.1 \% \mathrm{v} / \mathrm{v}), \mathrm{CaCl}_{2}(0.1 \% \mathrm{w} / \mathrm{v})$, and agar $(2 \% \mathrm{w} / \mathrm{v})$. The change in color of phenol red was used as an indicator

Table-1: Biochemical characteristics of different Aeromonas spp. [6].

\begin{tabular}{lccc}
\hline $\begin{array}{l}\text { Biochemical } \\
\text { tests }\end{array}$ & A. hydrophila & A. caviae & A. sobria \\
\hline Esculin hydrolysis & + & + & - \\
Gas from glucose & + & - & + \\
VP & + & - & $\mathrm{V}$ \\
Indole & + & + & + \\
Citrate & + & + & - \\
L-arabinose & + & - & + \\
$\mathrm{H}_{2}$ S production & + & $\mathrm{V}$ & $\mathrm{V}$ \\
Hemolysis & + &
\end{tabular}

for lipase activity, where lipase producing bacteria will turn the dye into yellow color.

\section{Results and Discussion}

Incidence of Aeromonas spp. in raw fish samples

The obtained data in Table- 2 revealed that Aeromonas spp. could be isolated from wild and cultured Nile tilapia samples with the percentage of $40 \%$ and $36 \%$, respectively. A. hydrophila strains could be isolated from wild and cultured Nile tilapia samples with the percentage of $16 \%$ and $12 \%$, respectively.

Regarding A. sobria, it could be isolated only from wild and cultured Nile tilapia in incidence of $20 \%$ and $24 \%$, respectively. Meanwhile, only wild Nile tilapia contaminated with one isolate of $A$. caviae with the percentage of $4 \%$ (Table-2).

The incidence of Aeromonas spp. was higher $(40 \%)$ in raw fish markets than that in aquaculture (36\%) (Table-2) which may be attributed to post-harvest contamination during handling, transportation, and selling through fishermen and fish vendors [8]. In comparison with the obtained results outlined in Table-2, nearly similar results $(39.58 \%)$ recorded by Gupta et al. [9] who found Aeromonas spp. in 38 samples of raw fish. On the contrary, higher results $(100 \%)$ of Aeromonas spp. in tilapia reported by Manna et al. [10] in a related study in India. On the other hand, lower incidence $(12 \%$ and $34 \%)$ of Aeromonas spp. obtained by Elshahid et al. [11] and Alhazmi [12], respectively, from raw fish samples. In this study, 3 A. hydrophila strains (with a percentage of $12 \%$ ) were isolated from 25 cultured Nile tilapia. On contrast, higher results achieved by El Deen et al. [13] who found that a total of 10 A. hydrophila strains (with a percentage of $25 \%$ ) were isolated from 40 cultured Nile tilapia collected randomly from the ponds of private fish farm in Kafr El Sheikh Governorate, Egypt.

Occurrence of Aeromonas spp. in RTE fish samples

Aeromonas spp. could be isolated from fried and grilled Bolti as well as fried Bayad samples with the percentage of $16 \%, 28 \%$ and $20 \%$, respectively (Table-3). A. hydrophila strains could be detected in

Table-2: Incidence of Aeromonas spp. in examined raw fish samples.

\begin{tabular}{lccccc}
\hline Samples & No. & \multicolumn{3}{c}{ N (\%) } \\
\cline { 3 - 5 } & & Aeromonas spp. & A. hydrophila & A. caviae & A. sobria \\
\hline Wild Nile tilapia & 25 & $10(40)$ & $4(16)$ & $1(4)$ & $5(20)$ \\
Cultured Nile tilapia & 25 & $9(36)$ & $3(12)$ & $0(0)$ & $6(24)$ \\
Total & 50 & $19(38)$ & $7(14)$ & $1(2)$ & $11(22)$ \\
\hline
\end{tabular}

Table-3: Incidence of Aeromonas spp. in examined RTE fish samples.

\begin{tabular}{lccccc}
\hline Samples & No. & \multicolumn{3}{c}{ N (\%) } \\
\cline { 3 - 6 } & & Aeromonas spp. & A. hydrophila & A. caviae & A. sobria \\
\hline Fried Bolti & 25 & $4(16)$ & $4(12)$ & $0(0)$ & $0(0)$ \\
Grilled Bolti & 25 & $5(28)$ & $6(24)$ & $0(0)$ & $1(4)$ \\
Fried Bayad & 25 & $16(21.3)$ & $15(20)$ & $0(0)$ & $0(0)$ \\
Total & 75 & & & $0(0)$ & $1(1.3)$ \\
\hline
\end{tabular}


fried Bolti and grilled Bolti, as well as fried Bayad samples with the percentage of $12 \%, 24 \%$ and $20 \%$, respectively (Table-3). Concerning A. sobria, it could be isolated only from grilled Bolti in incidence of $4 \%$ (Table-3).

In comparison with the obtained results outlined in Table-3, lower percentage (2.27\%) of Aeromonas spp. was isolated [9]. Meanwhile, a higher result $(77.3 \%)$ of RTE fry fish was found contaminated with Aeromonas spp. [10].

The obtained data demonstrated that out of 35 Aeromonas spp. isolates obtained, 22 were categorized as $A$. hydrophila, 12 were classified as A. sobria and A. caviae were found in only one isolate (Tables-2 and 3). Consequently, A. hydrophila and $A$. sobria predominate among potentially pathogenic Aeromonas isolates from examined raw and RTE fish. Similarly, many investigators pointed out that $A$. hydrophila was the most common isolate from foods of animal origin [14].

Many researchers could isolate A. hydrophila from Bagrus bayad such as Hussien and Salman [15] who reported that the bacterial isolates from the fresh B. bayad samples were $9 \%$ A. hydrophila and Elshahid et al. [11] who could isolate $A$. hydrophila from freshwater $B$. bayad with percentage of $16 \%$. The high contamination rate of RTE fish suggests recontamination after cooking caused by lack of hygiene and post-process contaminants from uncooked produce or contaminated water. The presence of Aeromonas spp. in grilled fish with large number $(28 \%)$ than fried fish $(16 \%)$ may be due to rapid grilling have been proved to be insufficient to kill all harmful microorganisms which may be present in raw fish prior to preparation.Further, the consumption of retailed grilled fish regarded as potential public health hazard.

\section{Detection of virulence factors of A. hydrophila}

The results presented in Table- 4 shown that hemolysin was produced by $86.4 \%$ of $A$. hydrophila, $100 \%$ of $A$. sobria, and $100 \%$ of $A$. caviae. In this study, the obtained results showed that $A$. hydrophila were able to hydrolyze the protein by protease enzyme $(77.1 \%)$ when tested on skim milk agar. Furthermore, Aeromonas isolates in this study had the ability to hydrolyze fats by lipase enzyme in $17.14 \%$ when cultured on phenol red olive oil agar for $3-5$ days at $37^{\circ} \mathrm{C}$ (Table-4).

Comparing with the results illustrated in Table-4, A. hydrophila showed positive result for hemolysin production (100\%), type beta ( $\beta$-hemolysin), when cultured on blood agar medium [7]. There was a strong correlation between the hemolysin and the virulence of A. hydrophila isolates. In a study conducted by Hatha et al. [16] recorded that $100 \%$ of A. hydrophila, $50 \%$ of $A$. sobria and $77.8 \%$ of $A$. caviae exhibited hemolytic activity. Moreover, Erdem et al. [17] reported that $A$. hydrophila and $A$. veronii biovar sobria strains were found to possess strong hemolytic activity, whereas A. caviae strains were nonhemolytic. In this study, the achieved results showed that $A$. hydrophila were able to hydrolyze the protein by protease enzyme (77.1\%) when tested on skim milk agar. On the other hand, higher percentage $(100 \%)$ was recorded by other authors as Al-Fatlawy and Al-Hadrawy [7], Pandey et al. [18] who emphasized that $A$. hydrophila was producing protease enzyme which able to hydrolyze the protein when tested on skim milk agar. Another study recorded proteolytic activity in $94.8 \%$ of Aeromonas strains [17]. Furthermore, lipase enzyme was present in $17.14 \%$ of Aeromonas isolates (Table-4). Higher incidence recorded by Al-Fatlawy and Al-Hadrawy [7] who emphasized the ability of $A$. hydrophila to hydrolyze fats by lipase.

Preventive method should be taken during food preparation; fish should be thoroughly cooked before consumption and good personal hygiene and proper sanitation procedure should always be used to prevent human exposure to this disease [5].

\section{Conclusions}

This study indicates that the presence of A. hydrophila with virulence potential in fresh and RTE fish may be a major threat to public health. Consequently, the public should be enlightened on the inherent danger that may accompany handling fresh fish or consumption of improperly cooked (either grilled or fried) fish.

\section{Authors' Contributions}

Study design, samples collection, laboratory work, and the manuscript writing were done by AMA. AMA has read and approved the final manuscript.

\section{Acknowledgments}

The author wishes to thank Prof. Dr. Talaat El-Khateib, Professor of Meat Hygiene, Department of Food Hygiene, Faculty of Veterinary Medicine, Assiut University, Assiut, Egypt for providing necessary facilities to carry out this study.

Table-4: Prevalence of virulence factors tested from Aeromonas spp.

\begin{tabular}{|c|c|c|c|c|c|c|c|}
\hline \multirow[t]{2}{*}{ Species } & \multirow{2}{*}{$\begin{array}{c}\text { Number of samples } \\
\text { tested }\end{array}$} & \multicolumn{2}{|c|}{ Hemolysin activity } & \multicolumn{2}{|c|}{ Protease activity } & \multicolumn{2}{|c|}{ Lipase activity } \\
\hline & & $+v e$ & $\%$ & +ve & $\%$ & $+v e$ & $\%$ \\
\hline A. hydrophila & 22 & 19 & 86.4 & 14 & 63.6 & 5 & 22.7 \\
\hline A. sobria & 12 & 12 & 100 & 12 & 100 & 1 & 100 \\
\hline A. caviae & 1 & 1 & 100 & 1 & 100 & 0 & 0 \\
\hline Total & 35 & 32 & 91.4 & 27 & 77.1 & 6 & 17.1 \\
\hline
\end{tabular}

+ ve $=$ Number of positive strains, $\%=$ Percentage of positive strains 


\section{Competing Interests}

\section{interests.}

The author declares that they have no competing

\section{References}

1. Batra, P., Mathur, P. and Misra, M.C. (2016) Aeromonas spp.: An emerging nosocomial pathogen. J. Lab. Physicians, 8(1): 1-4.

2. Janda, J.M. and Abbott, S.L. (2010) The genus Aeromonas: Taxonomy, pathogenicity, and infection. Clin. Microbiol. Rev., 23: 35-73.

3. Praveen, K.P., Debnath, C., Shekhar, S., Dalai, N. and Ganguly, S. (2016) Incidence of Aeromonas spp. infection in fish and chicken meat and its related public health hazards: A review. Vet. World, 9: 6-11.

4. Sanaa, O.Y. (2009) Isolation of Enterobacteriaceae and Pseudomonas species from raw fish sold in fish market in Khartoum state. J. Bacteriol. Res., 1: 85-88.

5. Ashiru, A.W., Uaboi-Egbeni, P.O., Oguntowo, J.E. and Idika, C.N. (2011) Isolation and antibiotic profile of Aeromonas spp. From Tilapia fish (Tilapia nilotica) and Catfish (Clarias betrachus). Pak. J. Nutr., 10: 982-986.

6. Erdem, B., Kariptaş, E., Cil, E. and Işik, K. (2011) Biochemical identifi cation and numerical taxonomy of Aeromonas spp. Isolated from food samples in Turkey. Turk. J. Biol., 35: 463-472.

7. Al-Fatlawy, H.N.K. and Al-Hadrawy, H.A. (2014) Isolation and characterization of $A$. hydrophila from the Al-Jadryia River in Baghdad (Iraq). Am. J. Educ. Res., 2: 658-662.

8. Abbas, M.S. (2014) Isolation of bacteria from fish. Int. J. Adv. Res., 2(3): 274-279.

9. Gupta, B., Ghatak, S. and Gill, J.P.S. (2013) Prevalence and characterization of pathogenic Aeromonas spp. Isolates from fish and fish products. J. Vet. Public Health, 11(1): 19-26.

10. Manna, S.K., Maurye, P., Dutta, C. and Samanta, G. (2013)
Occurrence and virulence characteristics of Aeromonas species in meat, milk and fish in India. J. Food Saf., 33: 461-469.

11. Elshahid, Y.S.Y., Ibrahim, H.A.A. and Samaha, I.A. (2009) Some Enteropathogenic Bacteria Isolated from Freshwater Fish at Alexandria Province. In: Proceedings of the $2^{\text {nd }}$ Global Fisheries and Aquaculture Research Conference, Cairo International Convention Center, 24-26 October. p725-740.

12. Alhazmi, M.I. (2015) Isolation of Aeromonas spp. From food products: Emerging Aeromonas infections and their significance in public health. J. AOAC Int., 98(4): 927-929.

13. El Deen, A.E.N., Dorgham-Sohad, M., Hassan-Azza, H.M. and Hakim, A.S. (2014) Studies on Aeromonas hydrophila in cultured Oreochromis niloticus at Kafr El Sheikh Governorate, Egypt with reference to histopathological alterations in some vital organs. World J. Fish Mar. Sci., 6(3): 233-240.

14. Igbinosa, I.H., Igumbor, E.U., Aghdasi, F., Tom, M. and Okoh, A.I. (2012) Emerging Aeromonas species infections and their significance in public health. Sci. World J., 2012: 625023 .

15. Hussien, A.H. and Salman, A.M.A. (2014) Aerobic bacterial contamination and shelf life of Bagrus bayad fish stored in crushed ice in Khartoum state. J. Appl. Sci., 2: 158-165.

16. Hatha, A.A.M., Vivekanandhan, G., Julie Joice and Christol (2005) Antibiotic resistance pattern of motile aeromonads from farm raised fresh water fish. Int. J. Food Microbiol., 98: 131-134.

17. Erdem, B., Kariptas, E. and Kaya, T. (2010) Siderophore, hemolytic, protease, and pyrazinamidase activities and antibiotic resistance in motile Aeromonas isolated from fish. Turk. J. Biol., 34: 453-462.

18. Pandey, A., Naik, M. and Dubey, S.K. (2010) Hemolysin, protease, and EPS producing pathogenic Aeromonas hydrophila strain An4 shows antibacterial activity against marine bacterial fish pathogens. J. Mar. Biol., 2010: 9. 